\title{
SISTEM INFORMASI MONITORING GURU AGAMA KATHOLIK TINGKAT SEKOLAH DASAR BERBASIS WEB
}

\author{
Ahmad Rofiq Hakim ${ }^{1)}$, Hj. Ekawati Yulsilviana ${ }^{2)}$, Cornelius Kurniawan' \\ ${ }^{1,2}$ Sistem Informasi, Stmik Widya Cipta Dharma \\ ${ }^{3}$ Sistem Informasi, Stmik Widya Cipta Dharma \\ 1,2,3 J1. Prof. M. Yamin No. 25, Samarinda, 75123 \\ E-mail : rofiq_93@yahoo.com ${ }^{1)}$, ekawati_stmik@yahoo.com ${ }^{2)}$, corneliuskurniawan@yahoo.com ${ }^{3)}$
}

\begin{abstract}
ABSTRAK
Website merupakan suatu bentuk informasi yang dapat memberikan kemudahan kepada user dalam melakukan proses laporan priodik serta mendapatkan informasi seputar kegiatan yang dibuat oleh pengawas dimana dan kapan pun user berada.

Penelitian dilakukan pada Kantor Kementerian Agama Kota Samarinda yang terletak di Jalan Harmonika. Metode pengumpulan data pada penelitian ini terdiri dari studi pustaka, wawancara, dan pengamatan langsung ke lapangan. Alat bantu pengembangan sistem yaitu flow of document, flowchart, context diagram, data flow diagram, entity relationship diagram, Site Map. Adapun kebutuhan perangkat lunak yang digunakan untuk membangun website antara lain menggunakan Web Server Apache, Database MySQL, Web Developer menggunakan PHP, Editor dan Web Design menggunakan Macromedia Dreamweaver MX serta Mozilla Firefox sebagai Browser.

Hasil penelitian sudah melalui beberapa pengujian yaitu menggunakan pengujian blackbox, white box dan pengujian betha. Banyak saran yang telah diberikan oleh para responden, maka saran-saran yang dapat diberikan penulis yaitu sistem ini masih dapat dikembangkan agar menjadi sistem website yang lebih baik dan efisien sesuai dengan kebutuhan dan perkembangan teknologi dan juga diperlukan pelatihan dalam bidang teknologi informasi sehingga penerapannya dapat dilaksanakan dengan baik.
\end{abstract}

Kata Kunci : Sistem Informasi, Monitoring, Guru Agama Katholik, WEB

\section{PENDAHULUAN}

Kementrian Agama Kota Samarinda sebagai instansi pemerintah yang menaungi guru agama dikota samarinda, berperan aktif melakukan pengawasan kinerja guru agama agar mampu melaksanakan tugas dengan baik, dengan melakukan monitoring/ pengawasan terhadap jalanya proses belajar mengajar di tingkat sekolah dasar khususnya di kota Samarinda.

Pengawas guru agama sebagai pihak yang mempunyai tugas dan fungsi melakukan monitoring terhadap guru agama secara langsung mempunyai wewenang penuh terhadap kinerja guru agama. Kesesuaiaan jam mengajar yang ditargetkan dengan materi yang disampaikan menjadi kunci utama penilaian kinerja guru agama. Setiap periode,guru agama akan mendatangi Kantor Kementrian Agama untuk melakukan pelaporan hasil pembelajaran dan konsultasi kepada pengawas guru.

Rutinitas ini membuat sebagian guru agama sering kali harus mengorbankan jam belajar untuk mengirimkan laporan hasil pembelajaran, dan jarak sekolah dasar di wilayah kota Samarinda, tersebar hingga ke pelosok, sehingga terkadang menyulitkan guru agama dalam melaporkan dan sering mengalami keterlambatan.Untuk mengatasi kendala yang dihadapi saat ini maka perlunya dibangun sebuah sistem informasi monitoring guru agama Katholik tingkat sekolah dasar, diharapkan sistem informasi berbasis web ini dapat diimplementasikan sehingga proses pelaporan oleh guru agama dapat berjalan dengan baik dan lebih menghemat waktu yang seharusnya digunakan untuk mengajar.

\section{RUANG LINGKUP PENELITIAN}

Dalam penelitian ini permasalahan mencakup :

1. Cakupan Masalah

Berdasarkan latar belakang yang telah diuraikan di atas, maka rumusan masalah penelitian ini adalah "Bagaimana membangun sebuah Sistem Informasi Monitoring Guru Agama Katholik tingkat sekolah dasar wilayah Samarinda berbasis Web".

2. Batsan-batasan penelitian

Permasalahan yang akan diangkat pada pembahasan ini adalah bagaimana menyediakan sistem informasi monitoring guru agama katholik tingkat sekolah dasar menggunakan bahasa pemrograman web PHP dan database MySQL. 
Adapun batasan masalah dalam penelitian ini adalah

\section{Halaman Guru Agama}

Pada halaman guru agama terdapat :

1. Informasi Sekolah

2. Informasi Guru

3. Upload Laporan Periodik

4. Surat Edaran

5. Forum Guru

6. Kontak

\section{Halaman Pengawas}

Pada halaman pengawas berisi halaman yang mengijinkan pengawas untuk melakukan tambah, ubah dan update terhadap halaman :

1. Informasi Sekolah

2. Informasi Guru

3. Menambahkan Surat Edaran

4. Download Laporan Periodik Guru

5. Forum Guru

6. Rekapitulasi Guru

7. Kontak

\section{Halaman Web Admin}

Pada halaman pengawas berisi halaman yang mengijinkan pengawas untuk melakukan tambah, ubah dan update terhadap halaman :

1. Pemeliharaan Data sekolah

2. Pemeliharaan Data Guru

3. Pemeliharaan Data Surat Edaran

4. Pemeliharaan Laporan Periodik Guru

5. Manajemen Forum Guru

Rencana hasil yang didapatkan :

Berdasarkan rumusan masalah di atas, maka tujuan penelitian ini adalah pembuatan sistem informasi monitoring guru agama Katholik tingkat sekolah agar dapat memudahkan para guru dalam melakukan peleporan kinerja kepada pengawas guru pada kementrian agama di kota samarinda, sehingga guru tidak perlu lagi langsung datang untuk memberikan laporan namun cukup dengan mengakses sistem informasi monitoring guru Agama Katholik tingkat sekolah dasar, dan melakukan upload laporan.

\section{BAHAN DAN METODE}

\subsection{Penjelasan Bahan}

Sistem Menurut Jogiyanto (2005), Sistem adalah kumpulan dari komponen-komponen yang dihubungkan dengan berbagai macam interaksi atau antara hubungan yang secara kolektif bereaksi terhadap rangsangan atau kebutuhan dan memenuhi suatu tujuan atau fungsi.

MySQL tergolong sebagai DBMS (Database Management System). Perangkat lunak ini bermanfaat untuk mengelola data dengan cara yang sangat fleksibel dan cepat. (Kadir, 2009)

Menurut Nugroho (2004), Sistem jaringan internet sendiri menyediakan arsitektur jaringan dan sementara web menyediakan metode untuk menyimpan dan mengambil dokumen-dokumennya. Web merupakan Framework arsitektur untuk memasuki dokumendokumen yang saling berhubungan yang terbesar diribuan komputer di seluruh internet.

\subsection{Metode}

Adapun tahapan yang terdapat dalam waterfall model dapat dijelaskan seperti di bawah ini:

1. Requirements analysis and definition: mengumpulkan kebutuhan secara lengkap kemudian dianalisis dan didefinisikan kebutuhan yang harus dipenuhi oleh program yang akan dibangun. Fase ini harus dikerjakan secara lengkap untuk bisa menghasilkan desain yang lengkap.

2. Sistem and Software design: desain dikerjakan setelah kebutuhan selesai dikumpulkan seecara lengkap.

3. Implementation and unit testing : desain program diterjemahkan ke dalam kode-kode dengan menggunakan bahasa pemrograman yang sudah ditentukan. Program yang dibangun langsung diuji baik secara unit.

4. Integration and sistem testing: penyatuan unitunit program kemudian diuji secara keseluruhan (sistem testing).

5. maintenance: mengoperasikan program dilingkungannya dan melakukan pemeliharaan, seperti penyesuaian atau perubahan karena adaptasi dengan situasi yang sebenarnya.

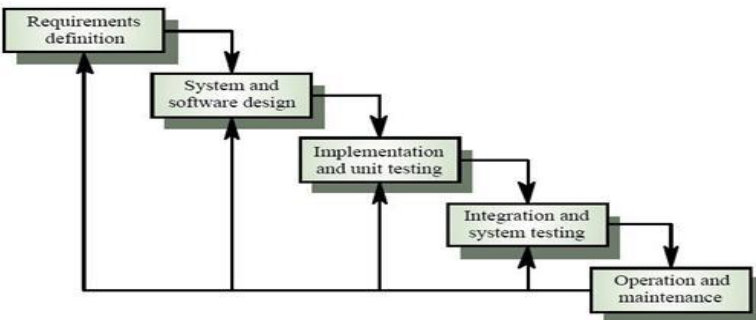

Gambar 1. Model Pengembangan Waterfall

\section{RANCANGAN SISTEM/APLIKASI}

Flow Of Document (FOD) Sistem Informasi Monitoring Guru Agama Katholik Tingkat Sekolah Dasar yang sedang berjalan

Flow Of Document (FOD) Sistem Informasi Monitoring Guru Agama Katholik Tingkat Sekolah Dasar yang sedang berjalan, proses dimulai dari guru agama dengan menyerahkan dokumen laporan periodik kepada pengawas sekolah untuk pemeriksaan dan pengawasan pengajaran guru agama Katholik. Kemudian pengawas sekolah membuat laporan dari hasil pengawasan terhadap kinerja guru agama, dalam bentuk laporan pengawas sekolah untuk diberikan kepada Kepala Kantor Kementerian Agama. Oleh Kepala Kantor Kementerian Agama, dijadikan dasar kebijakan mengenai metode dan evaluasi pendidikan agama Katholik. 


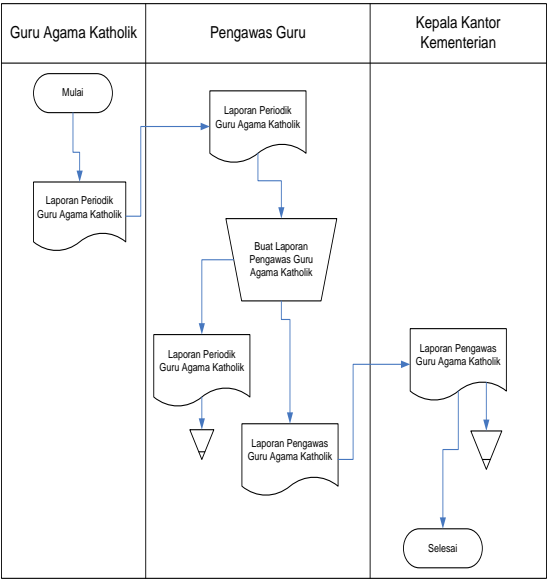

Gambar 2. (FOD) sedang berjalan.

1. Flow Of Document (FOD) Yang Diusulkan Sistem Informasi Monitoring Guru Agama Katholik Tingkat Sekolah Dasar yang diusulkan, proses dimulai dari guru agama dengan melakukan login sistem monitoring guru agama, kemudian melakukan input laporan periodik, dan database akan menampung laporan periodik, laporan periodik yang guru agama kirimkan akan ditampilkan agar guru agama dapat melihat laporan periodik yang telah dikirimkan telah terekam dalam database. pengawas guru akan melakukan pemeriksaan laporan periodik yang dikirimkan oleh guru agama. Kemudian pengawas sekolah membuat laporan dari hasil pengawasan terhadap kinerja guru agama, dalam bentuk laporan pengawas sekolah untuk diberikan kepada Kepala Kantor Kementerian Agama. Oleh Kepala Kantor Kementerian Agama, dijadikan dasar kebijakan mengenai metode dan evaluasi pendidikan agama Katholik.

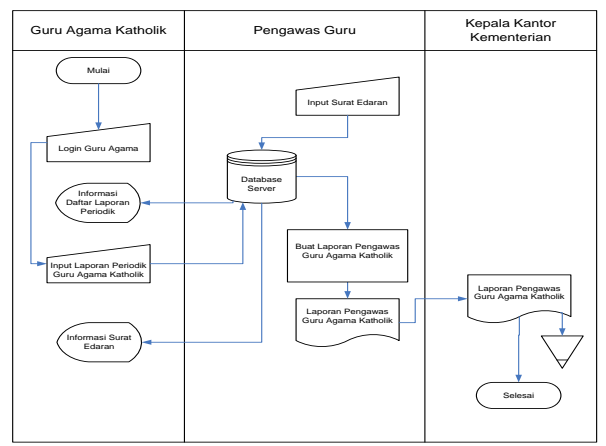

Gambar 3. FOD Yang Diusulkan

2. Flowchart sistem informasi monitoring guru Agama Katholik untuk guru agama, dapat digambarkan urutan-urutan proses yang terjadi. Adapun gambar dari proses unggah laporan periodik yang dibuat pada sistem informasi monitoring guru Agama Katholik

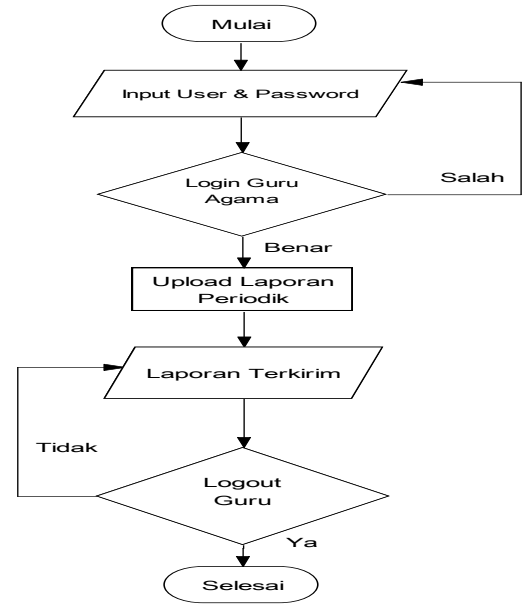

Gambar 3. Flowcart Pengiriman laporan Periodik untuk halaman Guru

3. Flowchart Sistem Informasi Monitoring Guru Agama Katholik digunakan sebagai alat untuk menjelaskan alur suatu proses monitoring guru agama Katholik yang ada pada sistem tersebut

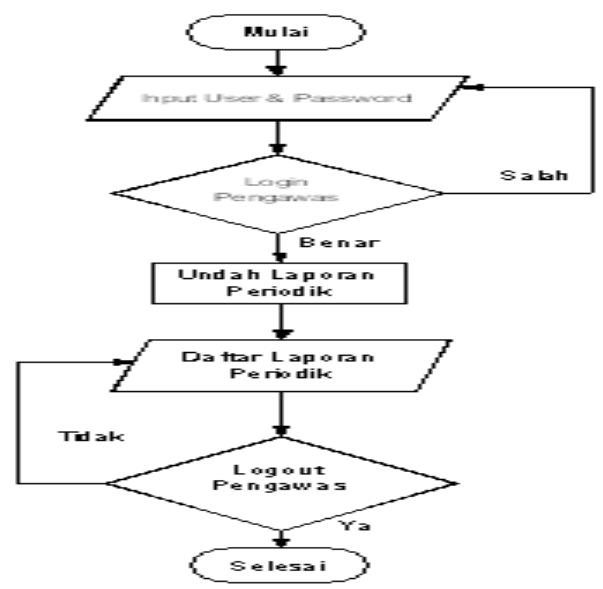

Gambar 4. Flowcart Unggah laporan Periodik untuk halaman Pengawas dan Admin

4. Context Diagram

1. Entitas Guru Agama

Entitas ini memberikan data guru secara lengkap, beserta unit sekolah tempat guru mengajar, pada akhir periode guru harus memberikan data laporan periodik guru agama Katholik dalam proses belajar mengajar selama periode tertentu.

2. Entitas Pengawas

Pengawas guru akan memeriksa file data loporan periodik guru agama Katholik untuk selanjutnya dipelajari dan disimpulkan untuk proses pelaporan kepada pimpinan tentang proses belajar-mengajar oleh guru agama.

3. Entitas Kepala Kantor Kementrian Agama Merupakan domain kebijakan pada kantor kementerian agama yang memperoleh laporan pengawas guru agama Katholik tentang kinerja 
guru agama Katholik dibawah naungan kantor Kementerian Agama kota Samarinda

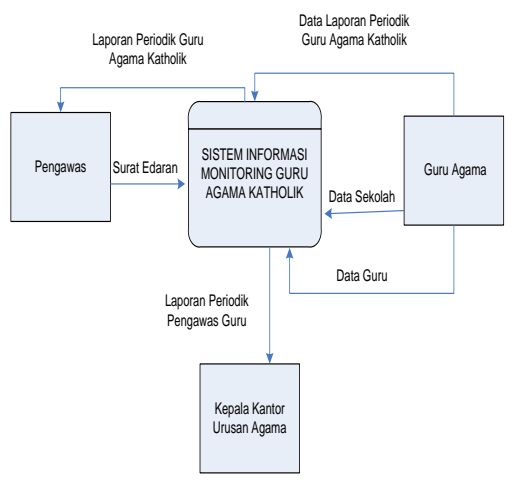

\section{Gambar 5. Diagram konteks Sistem Informasi Monitoring Guru Agama Katholik}

4. Data Flow Diagram (DFD) Level 0

Alir data sistem informasi monitoring guru agama Katholik tingkat sekolah dasar sebagai berikut :

1. Proses Pendataan Sekolah.

Entitas guru memberikan data sekolah tempat mengajar, selanjutnya data sekolah disimpan dalam tabel sekolah.

2. Proses Pendataan Guru Agama Katholik

Entitas Guru agama Katholik memberikan data diri, unit kerja/ sekolah tempat mengajar guru agama, dan data kepegawaian seperti status PNS dan pangkat/golongan. Data guru agama akan disimpan kedalam data store guru, dan data guru nantinya dapat digunakan pada proses laporan periodik guru agama Katholik dan login ke sistem informasi monitoring guru agama Katholik.

3. Proses Data Laporan Periodik Guru Agama Katholik

Data laporan periodik membutuhkan data guru agama, dan data sekolah, entitas guru agama akan melakukan upload file laporan periodik guru agama katholik ke dalam sistem, informasi laporan periodik periodik guru agama akan tersimpan kedalam tabel laporan periodik guru. Entitas Pengawas akan menerima berkas laporan periodik guru agama dari sistem.

4. Proses Pembaharuan surat edaran

Surat edaran diberikan oleh entitas pengawas kepada entitas guru agama Katholik.

5. Proses Pelaporan Laporan Pengawas Guru Agama

Entitas pimpinan Kantor Kementrian Agama menerima laporan periodik pengawas guru.

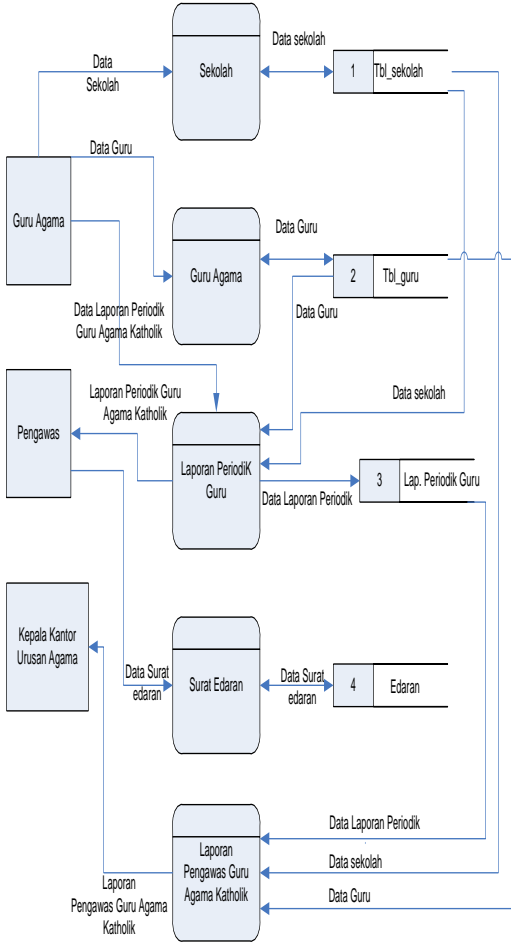

Gambar 6 Data flow diagram Level 0 Sistem Informasi Monitoring Guru Agama Katholik

\section{Data Flow Diagram (DFD) Level 1}

Data flow diagram Level 1 Sistem Informasi Monitoring Guru Agama Katholik, Entitas pimpinan Kantor Kementrian Agama menerima laporan pengawas guru agama Katholik, bersumberdari datastore tbl_sekolah yang memberikan data sekolah,tbl_guru memberikan data guru, dan datastore laporan periodik guru memberikan data laporan periodik guru.

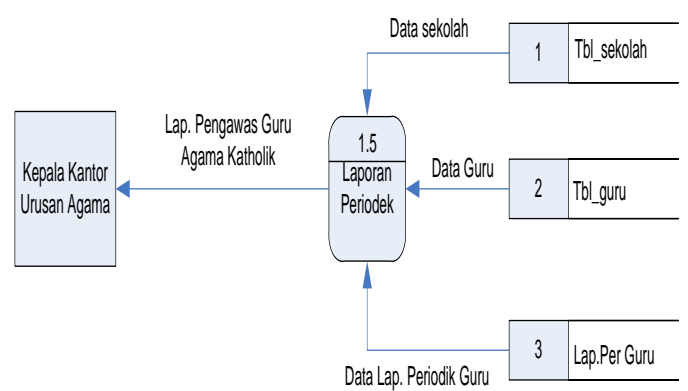

Gambar 7. Data flow diagram Level 1 Sistem Informasi Monitoring Guru Agama Katholi 


\section{IMPLEMENTASI}

\section{Halaman Utama User}

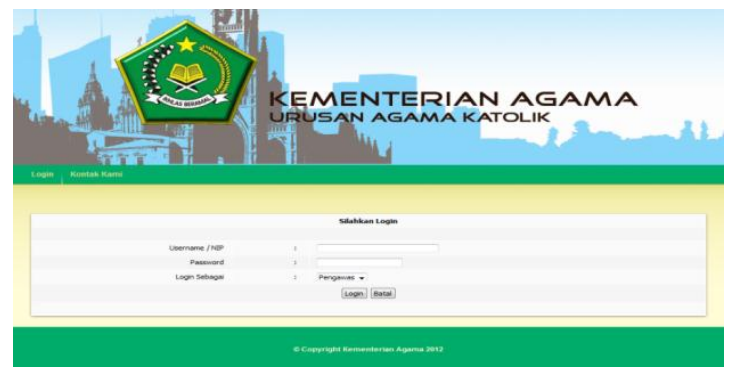

Gambar 8. Halaman Utama User

Halaman user merupakan halaman utama dari web ini, halaman dimana yang telah mendapatkan user dan password yang dapat melakukan pelaporan data periodik guru agama Katholik Tampilan Form Input Data Mekanik

\section{Halaman Profil Kantor Kementrian Agama}

Halaman index merupakan halaman utama saat membuka website ini. Halaman ini berisi tampilan dasar profil Kementerian Agama urusan agama Katholik, beserta visi dan misi yang diemban. Sepe

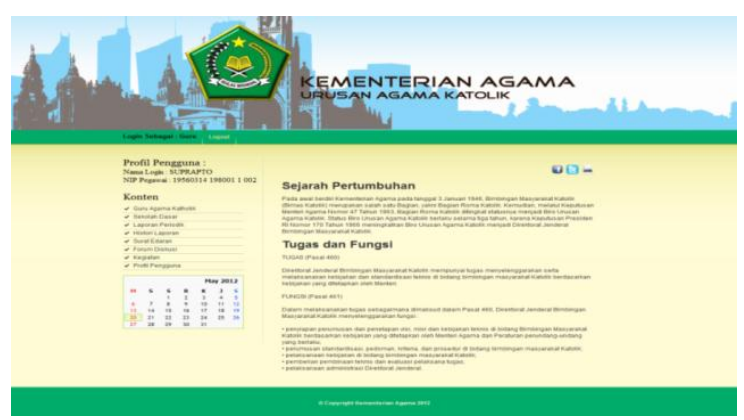

Gambar 9. Halaman Visi dan Misi Kantor Kementerian Agama

\section{Halaman Guru agama}

Halaman ini merupakan halaman untuk melihat daftar guru agama yang menjadi komponen utama sistem ini dan dan bernaung dibawahi Kantor Kementrian Agama urusan agama Katholik di Samarinda.

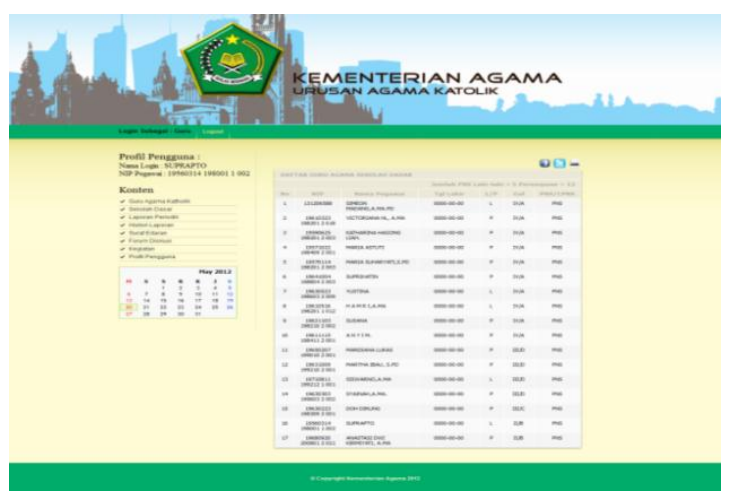

Gambar 10. Halaman Daftar Guru Agama

\section{Halaman Daftar Sekolah Dasar}

Halaman ini merupakan halaman data sekolah dasar tempat guru agama Katholik mengajarkan materi agama diwilayah samarinda, lengkap dengan alamat, nama kepala sekolah.

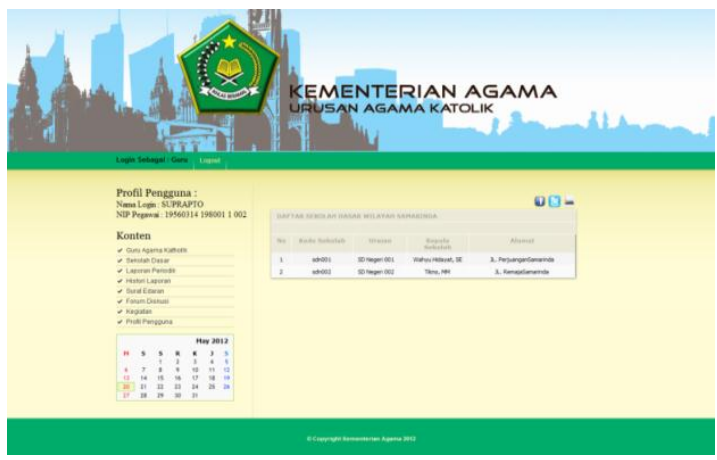

Gambar 10. Halaman Daftar Sekolah Dasar

\section{Halaman Upload Laporan Periodik}

Halaman ini merupakan halaman utama modul laporan periodik guru agama Katholik, guru agama dapat mengirimkan laporan dalambentuk dokumen atau yang telah dikompres agar mudah dalam pengiriman data. Laporan yang telah dikirimkan akan langsung tercatat sebagai laporan bulan berjalan oleh sistem.

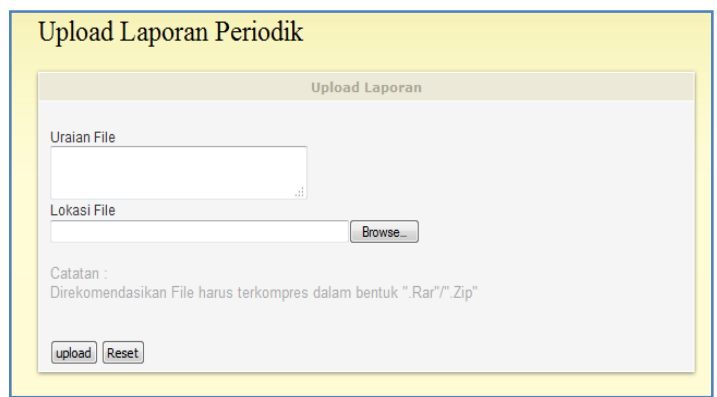

\section{Gambar 11. Halaman Upload Laporan Periodik}

\section{Halaman Daftar Laporan Periodik}

Halaman ini merupakan halaman yang berisi daftar file yang telah di upload oleh guru agama, beserta nama file yang terlampir serta tanggal pengiriman file laporan periodik yang pernah dilakukan.

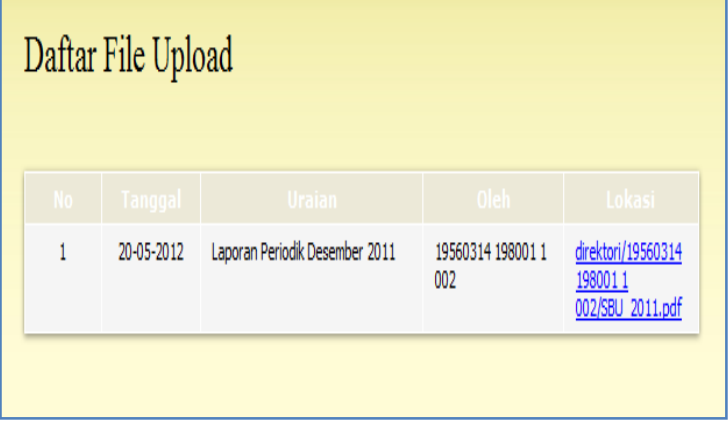

Gambar 12. Form Laporan yang sudah di Upload 


\section{Halaman Daftar Surat Edaran}

Halaman ini merupakan tampilan daftar surat edaran yang selalu dilakukan update oleh admin dan pengawas sekolah dalam memberikan informasi terkait kegiatan di lingkungan kementrian agama khususnya wilayah samarinda. Surat edaran dapat di lihat file gambar surat edaran, jika gambar surat edaran telah dilampirkan sebelumnya.

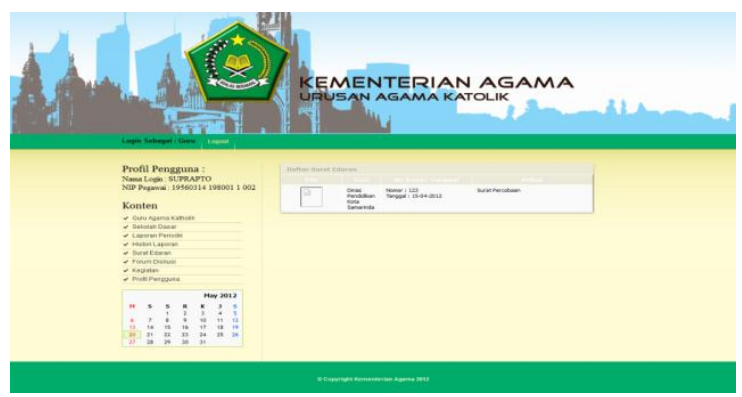

Gambar 13. Daftar Surat Edaran

\section{Halaman Daftar Surat Edaran}

Halaman ini merupakan tampilan daftar surat edaran yang selalu dilakukan update oleh admin dan pengawas sekolah dalam memberikan informasi terkait kegiatan di lingkungan kementrian agama khususnya wilayah samarinda. Surat edaran dapat di lihat file gambar surat edaran.

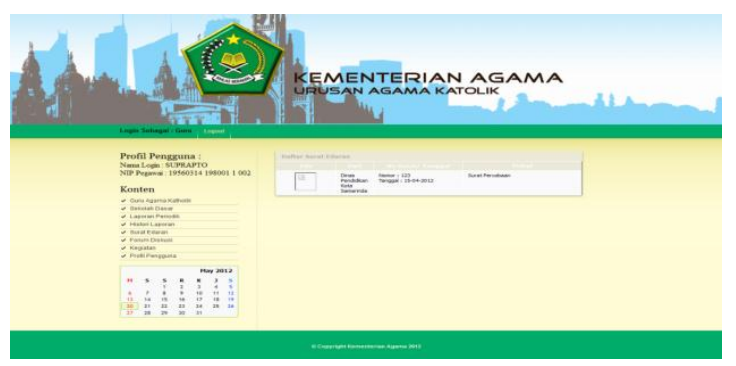

Gambar 14. Daftar Surat Edaran

\section{Halaman Forum Diskusi}

Sebelum melakukan diskusi pada forum, guru maupun pengawas terlebih dahulu masuk ke kategori forum, setelah itu dapat memilih topik pembahasan yang ingin ditanggapi atau ingin membuat topik pembahasan baru. Setiap tanggapan dengan jumlah komentar paling banyak akan menjadi topik populer.

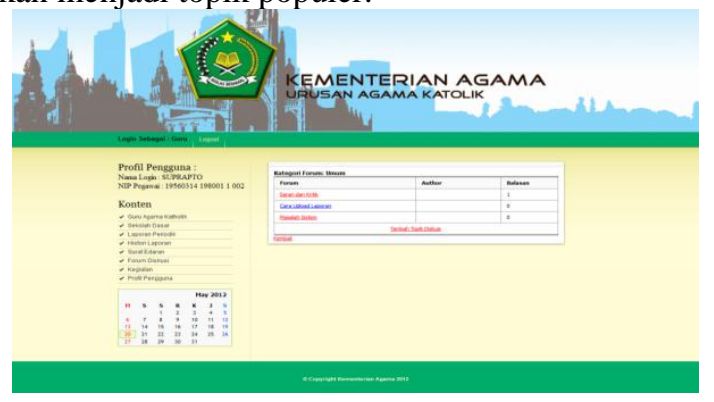

Gambar 15. Kategori Forum

\section{Halaman Daftar Kegiatan}

halaman kegiatan yang akan dilaksanakan olah lingkungan kantor Kementerian Agama kota samarinda untuk urusan agama Katholik. Informasi padahalaman ini meliputi nama kegiatan, tanggal kegiatan dan tempat pelaksanaan kegiatan tersebut berlangsung. Untuk menambahkan kegiatan ini, dilakukan oleh admin dan pengawas sekolah, guru agama hanya melihat informasi kegiatan saja.

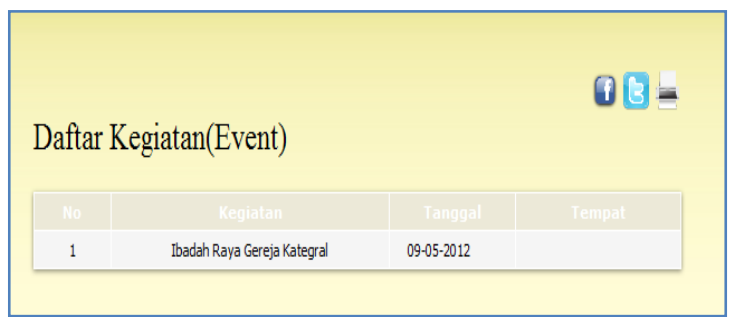

Gambar 16. Halaman Kegiatan

11. Halaman Profil Pengguna atau Guru Agama Pada halaman ini akan ditampilkan secara terinci identitas guru agama mulai dari nomor induk pegawai, nama lengkap guru, golongan, tempat mengajar, dan alamat dan user yang digunakan untuk melakukan login sistem monitoring ini, beserta foto diri, yang memudahkan pengawas sekolah dalam mengenali guru agama yang bertugas di lingkungan Kantor Kementerian Agama samarinda, dan terdapat informasi jumlah laporan yang pernah dikirimkan oleh guru agama.

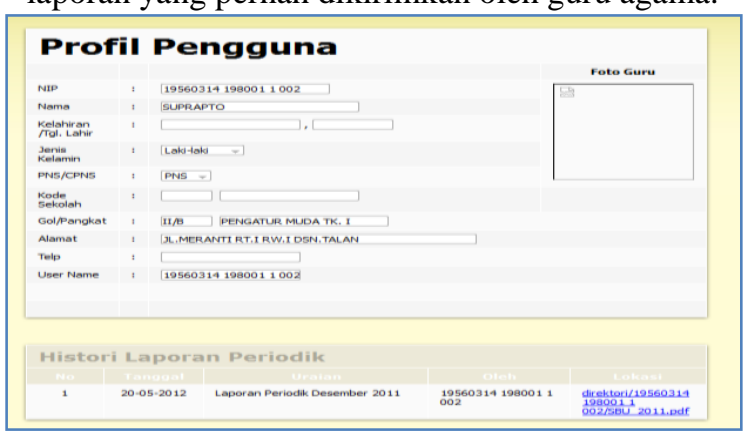

Gambar 17. Halaman Profil Guru Agama

\section{KESIMPULAN}

Setelah penulis mengadakan penelitian pada kantor Kementerian Agama urusan Agama Katholik di Samarinda, maka penulis dapat menyimpulkan sebagai berikut :

1. Dengan adanya Sistem Informasi Monitoring Guru agama Katholik Pada Kantor Kementerian Agama Samarinda dengan menggunakan pemrograman berbasis web, diharapkan dapat mengefisiensikan waktu dalam proses penyampaiaan laporan proses belajar mengajar dari guru agama katholik kepada pengawas guru.

2. Sistem yang telah dibangun ini dapat mengetahui komposisi jumlah guru agama dan sekolah dasar yang menjadi tempat pengajar agama katholik ditempatkan. 
3. Data laporan periodik bersifat dinamis, sehingga memudahkan guru agama dalam memberikan laporan setiap bulanya kepada pengawas guru agama Katholik khususnya tingkat sekolah dasar.

\section{SARAN}

Adapun saran yang penulis berikan kepada Kementerian Agama urusan agama Katholik, untuk kelancaran proses pelaporan proses belajar mengajar guru agama Katholik tingkat sekolah dasar diwilayah samarinda adalah :

1. Diharapkan Kementerian Agama urusan agama Katholik di Samarinda dapat memberikan domain resmi agar poses pelaporan data periodik guru agama katholik dapat diwujudkan.

2. Sitem yang berjalan ini masih dapat dikembangkan lebih jauh dengan menyempurnakan keamanan web dan menggali penggunaan Jquery dalam menghasilkan tampilan dan proses yang menarik.

3. Agar Sitem ini dapat menjadi forum komunikasi guru agama dan pengawas guru agama Katholik, dan informasi yang ada didalamnya dapat selalu Update sesuai kebutuhan informasi saat ini.

\section{DAFTAR PUSTAKA}

Andi. 2005. Aplikasi Manajemen Database Pendidikan Berbasis Web dengan PHP dan MySQL. Yogyakarta: Andi Yogyakarta.

Fathansyah. 2004, Basis Data, Informatika Bandung.

Jogiyanto HM. 2005, Analisa dan Desain, Yogyakarta: Andi offset.

Kadir, Abdul. 2003, Pengenalan Sistem Informasi. Yogyakarta : Andi.

Kristanto Andi, 2007, Perancangan Sistem Informasi dan Aplikasinya, Yogyakarta : Gava Media.

Nugroho, Bunafit. 2004. PHP \& MySQL dengan Editor Dreamweaver MX. Yogyakarta: Andi Yogyakarta.

Purbo, Onno W dan Sembiring, Akhmad D. 2000. Buku Pintar Internet APACHE WEB SERVER. Jakarta: PT. Elex Media Komputindo

Pusat Bahasa Departemen Pendidikan Nasional 2008, Kamus Besar Bahasa Indonesia, Edisi IV, Jakarta : Balai Pustaka.

Pressman,Roger S,2002, Rekayasa Perangkat Lunak : pendekatan praktisi(bukuI), Yogyakarta : Andi

Prayitno M.Sc.Ed 2005 Paduan Kegiatan Pengawasan Bimbingan dan Konseling di Sekolah.

Suyantoro 2007, Web Design Theory and fractices. Yogyakarta : Andi

Sutabri, Tata,2004, Analisa sistem informasi, Yogyakarta : Andi 